\title{
Brazil struggles to cope with Zika epidemic
}

Tom Hennigan visits Recife, the Brazilian city at the centre of what is now a global health emergency, to see how the country's public health system is coping

\section{Tom Hennigan freelance journalist}

São Paulo, Brazil

Silvana Nascimento was already into her third trimester before doctors noticed that her fetus probably had microcephaly. And even then the warning signs were picked up only after she was transferred $170 \mathrm{~km}$ from her rural Brazilian village to a public hospital in the city of Recife because of complications associated with her diabetes.

The 23 year old mother of three was not aware of the risk associated with the mosquito borne Zika virus until after she became pregnant but was not unduly concerned. "No one in our area was giving birth to babies with small heads, and if I caught Zika I definitely didn't notice it," she says from her bed in Dom Pedro II maternity hospital, part of Pernambuco's Mother and Child Institute (IMIP).

She says a government programme to provide free insect repellent to expectant mothers never reached her community. In a poor agricultural region of Pernambuco state, Nascimento's village of Sertãozinho de Baixo has a public health clinic "but it's closed more often than it's open," and with the nearest maternity unit $20 \mathrm{~km}$ away over broken country roads she had had only one obstetric ultrasound examination, which failed to pick up any problems.

Though she praises the care she has received since her arrival at what is a reference centre for maternity care across the country's poor north eastern region, Nascimento's story highlights the problems Brazil's public health system faces in tackling the Zika epidemic linked to a spike in microcephaly.

It was only September last year that doctors began to report an alarming rise in the number of babies being born with microcephaly. By November a possible link had been made with the Zika epidemic when tests from two women whose babies were showing signs of microcephaly showed high levels of the virus in their amniotic fluid. As of 23 February, 4107 cases of microcephaly had been reported for investigation, with 583 cases already confirmed as associated with Zika virus and 950 discarded, according to health ministry figures. The federal government is fighting hard against the Aedes aegypti mosquito, deploying the military to help communities eliminate its breeding grounds. But a severe financial crisis meant that the public health system was already under severe stress before the Zika epidemic hit it.

\section{Overstretched services}

"Within the SUS [Sistema Único de Saúde or Unified Health System, the country's version of the NHS] there are islands of excellence in teaching hospitals like Dom Pedro II and those linked to universities. But in general it leaves a lot to be desired for those in need," says Adriana Scavuzzi, women's health coordinator at IMIP. "Zika hit a maternity system that was already chaotic. It is desolating to see these women going through this situation when they are being so poorly looked after."

Even in the relatively well equipped Dom Pedro II, medics report a system straining under the extra demands now placed on it by the epidemic, with anxious women demanding scans at any hint of sickness. "The demand for ultrasounds is now greater than we can meet but we are trying to do as much as possible, working extra hours, doing what we can to help the mothers," says Alex Souza of IMIP's fetal health unit.

As part of the problem Souza highlights the delay in getting back results of Zika tests. "We do not have the speed and agility we need. Ultrasound results are immediate, but blood and urine tests can take 15 days to a month. The authorities understand what we need but the resources are scarce."

Zika and microcephaly are hitting poorer communities hardest as they are more likely to have poor water and sanitation services-only half of the country's residences are connected to a sewage system. And the crisis in the public health system worsens the further you get from state capitals such as Recife. "Even before Zika the interior lacked doctors, nurses, and specialists. The ability there to identify fetuses with microcephaly is compromised by the fact many rural municipalities just have obstetric ultrasounds and for anything more sophisticated they have to be sent to us in the capital," Souza says. 
The uneven distribution of limited resources in Brazil's public health service is not just an urban-rural divide. Recife's Agamenon Magalhães hospital does not qualify as one of Scavuzzi's islands of excellence. A walk through the hospital makes clear why Pernambuco's health authorities direct visiting press elsewhere.

At Agamenon Magalhães, outpatient waiting areas are thronged from early morning while one of the maternity wards' corridors is crowded with heavily pregnant women on trolleys and in wheelchairs, some attached to drips. Health professionals speaking off the record because they were not authorised to talk to media told of a lack of staff and resources exacerbated by the Zika epidemic.

One patient, Viviane de la Ponte, developed a fever and rash in her first trimester. She and her husband, Thiago, fear that she might have caught Zika virus, with possible implications for their unborn child. "We have been waiting a month for the test results to see what she caught. She did one test back in November and we still have not got the results. The SUS is horrible; it is so disorganised," he says.

While praising the success of Brazil's public health notification system, which quickly picked up the spike in microcephaly and its probable link to the spreading Zika epidemic, researchers acknowledge stresses in the system.

"In Pernambuco health authorities implemented impeccable procedures and quickly informed the population about what to do. But in terms of implementation through the SUS we are seeing a lack of resources because there has been an increase in demand for specific services," says Laura Rodrigues, a professor at the London School of Hygiene and Tropical Medicine who is helping lead one of the Zika task forces back in her native Brazil.

She identifies delays with blood tests, shortages of computed tomography facilities, and insufficient physical and speech therapists for babies born with microcephaly. "This is all a question of budget."
"The situation now is very demanding," says Scavuzzi. "Because of Zika what I thought were the worst conditions possible have become even worse. But as a frontline doctor you cannot just give up." She fears that if extra funding is not found, some doctors may leave for the private sector. This is already a problem in the SUS.

Brazil is the destination for the majority of the $\$ 56 \mathrm{~m}$ ( $£ 40 \mathrm{~m}$; $€ 52 \mathrm{~m}$ ) that the World Health Organization has earmarked for its response to the Zika epidemic. Brazil's failure in recent years to halt the spread of dengue virus, which infected 1.6 million people last year killing over 800 , does not bode well for the battle to contain the spread of Zika despite the deployment of 200000 military personnel on the streets. Public awareness has increased because of a public health campaign, with President Dilma Rousseff saying the country will not be defeated by a mosquito. On a recent visit to Brazil WHO president, Margaret Chan, praised the government's response. But the virus continues to spread into new regions, and WHO predicts that 1.5 million Brazilians will be infected with Zika virus this year. With a vaccine still some way off, the country is left tackling the legacy from decades of underinvestment in public sanitation-the pools of standing water endemic in poor neighbourhoods where the mosquito thrives. Though vital to defeating the disease's vector this battle cannot be won quickly, especially in a country being forced to slash investment as a result of a severe fiscal crisis.

Competing interests: I have read and understood BMJ policy on declaration of interests and have no relevant interests to declare. Provenance and peer review: Commissioned; not externally peer reviewed.

1 Monteiro MFG, Adesse L, Drezett J. Update to the estimates of the magnitude of the induced abortion rates per thousand women and reasons for 100 live births induced abortion by age group and major regions. Brasil, 1995 to 2013[in Portuguese]. Reprod Clim 2015;30:11-8.

Published by the BMJ Publishing Group Limited. For permission to use (where not already granted under a licence) please go to http://group.bmj.com/group/rights-licensing/ permissions 


\section{Abortion risks}

Though doctors and women's rights campaigners in Brazil agree that the Zika epidemic has yet to provoke an identifiable increase in the number of illegal abortions in Brazil they expect it is only a matter of time.

Already the epidemic has sparked a battle between pro-abortion and anti-abortion campaigners in the country, where the procedure is permitted only in cases of rape, when the mother's life is at risk, or for anencephaly. Nevertheless, despite Brazil being a traditional Catholic country with a growing evangelical Protestant population, abortion is common, with estimates ranging from 100000 to over one million each year. A study by local researchers using the Guttmacher Institute methodology estimated that in 2013 there were between 684000 and 860 000 abortions. ${ }^{1}$

Fearing mothers will seek to abort fetuses that might have microcephaly, conservatives in Congress are trying to increase penalties for women who have terminations. Women convicted of having an abortion face one to three years in jail, with doctors facing up to four years. Meanwhile women's rights campaigners are petitioning the Supreme Court to allow abortion for women displaying symptoms of Zika infection. "Given the uncertainty in the middle of an epidemic and the historic responsibility of the Brazilian state for failing to eliminate the mosquito vector we are saying these women have the right to choose, because many of them are now going through psychological torture," says Debora Diniz cofounder of the Institute of Bioethics, which is presenting the case to the Supreme Court. 